\title{
Manajemen Perencanaan Dan Pelaksanaan Pendidikan Islam di Madrasah Aliyah Al-Hidayah Ibun
}

Yuli Supriani ${ }^{1}$, Hendri Juhana ${ }^{2}$, Hakin Najili ${ }^{3}$, Muhibbin Syah ${ }^{4}$, Muhammad Erihadiana ${ }^{5}$

1,2,3,4,5Universitas Islam Negeri Sunan Gunung Djati Bandung, Indonesia

E-mail:yulisupriani30@gmail.com, hendrijuhana1@gmail.com, hakinnajili35@gmail.com, muhibbinsyah@yahoo.com, erihadiana@uinsgd.ac.id

\begin{abstract}
Article Info
Article History

Received: 2021-10-09

Revised: 2021-11-02

Published: 2021-11-28
\end{abstract}

Keywords:

Planning;

Implementation;

Education;

Islam.

\begin{abstract}
The purpose of this study was to obtain an overview and analyze the Management of Planning and Implementation of Islamic Education in the learning process. The research method used in this qualitative approach is the case study method. A research method that aims to describe a particular situation or field in an analytical, factual and systematic manner. The results of this study indicate that: 1) Islamic education planning in the learning process at MA Al-Hidayah Ibun is as follows: a) The teacher makes learning tools, b) The teacher sets learning objectives, c) The teacher selects and develops teaching materials, d) The teacher chooses appropriate teaching media, and e) The teacher selects and utilizes learning resources. 2) The implementation of Islamic education in the learning process at MA Al-Hidayah Ibun are as follows: a) The teacher creates the right learning climate/atmosphere, b) The teacher observes learning activities, c) The teacher organizes students in learning activities, d) The teacher chooses and determines the method learning that is considered the most appropriate and effective, e) The teacher assesses the learning achievement of students, and f) The teacher carries out a follow-up on the results of the assessment.
\end{abstract}

\begin{tabular}{l}
\hline Artikel Info \\
\hline Sejarah Artikel \\
Diterima: 2021-10-09 \\
Direvisi: 2021-11-02 \\
Dipublikasi: 2021-11-28
\end{tabular}

Kata kunci:

Perencanaan;

Pelaksanaan;

Pendidikan;

Islam.

\section{PENDAHULUAN}

Perkembangan ilmu pengetahuan dan teknologi sangat turut menentukan arah perkembangan masyarakat dewasa ini, yang secara langsung berkaitan erat dengan dunia pendidikan, namun persoalan yang sering muncul adalah menyangkut lulusan yang apabila dihadapkan pada kebutuhan tenaga kerja, sangat terasa betapa rendahnya kualitas sumber daya manusia di negara kita, menurut (Mayasari, 2021) bahwa salah satu faktor penyababnya adalah menyangkut sistem dan manajemen penyelenggaraan pendidikan, perencanaan dan pelaksanaan sebagai salah satu fungsi organik dalam manajemen, merupakan bagian integral dari fungsi-fungsi organik lainnya di dalam manajemen. Menurut (Hasbi, 2021) bahwa dalam proses kerjanya perencanaan dan pelaksanaan menerima masukan dari fungsi-fungsi organik manajemen lainnya, misalnya dari fungsi organik pengorganisasian menerima masukan yang berupa tujuan organisasi, dari fungsi organik pengawasan menerima masukan umpan balik berupa laporan hasil pelaksanaan suatu rencana. Selain masukan dari fungsi-fungsi organik manajemen lainnya, menurut (Bairizki, 2021) bahwa kegiatan perencanaan dan pelaksanaan juga memerlukan masukan instrumental yang 
terdiri atas program pengajaran tenaga, metode, instrumen, organisasi dan biaya perencanaan.

Dalam suatu kegiatan apa pun bentuknya, perencanaan merupakan faktor yang sangat penting dan strategis sebagai pemandu arah bagi pelaksanaan suatu kegiatan dalam rangka mencapai tujuan/ sasaran/ target yang diinginkan. Menurut (Juhji, 2020) bahwa perencanaan sebagai suatu rangkaian proses kegiatan, dilakukan untuk menyiapkan keputusan mengenai apa yang diharapkan terjadi dan yang akan dilakukan. Dalam pengertian yang luas, perencanaan dapat dimaknai sebagai suatu proses mempersiapkan kegiatan-kegiatan secara sistematis yang akan dilakukan untuk mencapai tujuan tertentu.

Menurut UU Nomor 20 tahun 2003 tentang sistem Pendidikan Nasional, Pendidikan adalah usaha sadar dan terencana untuk mewujudkan suasana belajar dan proses pembelajaran agar peserta didik secara aktif mengembangkan potensi dirinya untuk memiliki kekuatan spiritual keagamaan, pengendalian diri, kepribadian, kecerdasan, akhlak mulia, serta keterampilan yang diperlukan dirinya, masyarakat, bangsa dan Negara, dalam bidang pendidikan Islam, perencanaan merupakan salah satu faktor efektivitas terlaksananya kegiatan pendidikan untuk mencapai tujuan pendidikan. Pentingnya perencanaan dan pelaksanaan bidang pendidikan Islam karena pendidikan Islam diyakini oleh umat Islam sebagai jalan hidup manusia yang paling baik, sehingga Pendidikan Islam benarbenar dapat menyejahterakan setiap Muslim, baik di dunia maupun di akhirat. Namun dalam pelaksanaan pendidikan Islam, perencanaan dan pelaksanaan pendidikan baru atau masih lebih banyak dijadikan faktor pelengkap. Penyebabnya adalah karena para perencana pendidikan kurang memahami proses dan mekanisme perencanaan dalam konteks yang lebih komprehensif, selain itu, posisi bidang perencanaan belum merupakan faktor kunci keberadaan suatu lembaga pendidikan, baik pada tingkat makro maupun mikro.

Istilah "Islam" dalam pendidikan menunjukkan bahwa pendidikan disini merupakan pendidikan yang mengandung corak Islami, sehingga seluruh komponen yang terkandung dalam kegiatan pendidikan berdasarkan ajaran Islam. Lalu apa pengertian pendidikan dalam pandangan Islam itu sendiri? sebelum menjawab pertanyaan tersebut kita harus tahu dulu apa arti pendidikan menurut pakar-pakar pendidikan. Pendidikan menurut Zuhairini dalam (Arifudin,
2021) mengemukakan bahwa suatu aktivitas untuk mengembangkan seluruh aspek kepribadian manusia yang berjalan seumur hidup. Menurut (Muhibin, 2008) bahwa pendidikan pada hakikatnya adalah pengembangan potensi atau kemampuan manusia secara menyeluruh yang pelaksanaannya dilakukan dengan cara mengajarkan berbagai pengetahuan dan kecakapan yang dibutuhkan oleh manusia itusendiri. Sedangkan menurut (Tafsir, 2012) bahwa Pendidikan adalah bimbingan atau pimpinan secara sadar oleh pendidik terhadap perkembangan jasmani dan rohani anak didik menuju terbentuknya kepribadian yang utama.

Definisi di atas telah menunjukkan bahwa pendidikan adalah suatu cara untuk mendidik seorang agar mencapai tujuan tertentu dalam pendidikan itu sendiri. Begitu juga dengan pendidikan menurut Islam yaitu bimbingan yang diberikan kepada orang lain agar berkembang sesuai dengan dasar-dasar ajaran Islam. Sebab dalam pendidikan Islam terkandung arahan yang menunjukkan terhadap perbaikan sikap mental dan tingkah laku yang sesuai dengan ajaran Islam baik itu untuk diri sendiri maupun orang lain. Dari sini dapat dijelaskan bahwa pendidikan dalam Islam ialah bimbingan seorang pendidik terhadap anak didik sesuai dengan ajaran Islam agar menjadi seorang muslim yang seutuhnya.

Pendidikan Islam merupakan bagian dari sistem pendidikan nasional memiliki peran strategis dalam mencerdaskan kehidupan bangsa dan memajukan ilmu pengetahuan dan teknologi. Sebagai upaya meningkatkan mutu pendidikan, Pendidikan Islam menggunakan pendekatan manajemen dalam penyelenggaraan pendidikan. Secara khusus dalam penelitian ini pendekatan manajemen yang digunakan adalah perencanaan dan pelaksanaan.

Fungsi paling awal dari semua menejemen. Perencanaan adalah proses kegiatan untuk menyajikan secara sistematis segala kegiatan yang akan dilaksanakan untyuk mencapai tujuan tertentu. Menurut Early Suandy dalam (Arifudin, 2018) mendefinisikan perencanaan adalah "proses penentuan tujuan organisasi (perusahaan) dan kemudian menyajikan (mengartikulasikan) dengan jelas strategi-strategi (program), taktik-taktik (tata cara pelaksanaan program) dan operasi (tindakan) yang di perlukan untuk mencapai tujuan perusahaan secara menyeluruh", pengertian perencanaan di atas dapat diartikan sebagai penetapan tujuan, budget, policy prosedur, dan program suatu 
organisasai. Dengan adanya perencaan, fungsi menejemen berguna untuk menetapkan tujuan yang akan dicapai, menetapkan biaya, menetapkan segala peraturan-peraturan dan pedomanpedoman yang harus dilaksanakan. Perencanaan meliputi beberapa aspek, diantaranya apa yang akan dilakukan, kapan dilakukan, dimana akan dilakukan, bagaimana cara melakukannya, apa saja yang dibutuhkan agar tercapai tujuan dengan maksimal. Dengan kata lain, bahwa perencanaan adalah penentuan tujuan yang akan di capai, memilih, dan menentukan cara apa yang di tempuh untuk mencapai tujuan, dan usahausaha atau cara-cara yang akan di tempuh untuk mencapai tujuan.

Selanjutnya adalah Pelaksanaan yang berfungsi untuk merealisasikan hasil perencanaan. Pelaksanaan merupakan salahdalam satu fungsi manajemen. Fungsi ini merupakan fungsi fundamental manajemen sebagai tindak lanjut dari fungsi perencanaan dan pengorganisasian. Menurut G. Terry dalam (Hasibuan, 2016) bahwa Pelaksanaan adalah "tindakan untuk mengusahakan agar semua anggota kelompok berusaha dengan sepenuh hati untuk mencapai sasaran agar sesuai dengan perencanaan manajerial dan usaha-usaha organisasi", pelaksanaan menurut (Nadeak, 2020) merupakan usaha untuk mengarahkan atau menggerakan tenaga kerja atau man power dan mendayagunakan fasilitas yang tersedia guna melaksanakan pekerjaan secara bersamaan, fungsi ini memotifasi bawahan atau pekerja untuk bekerja dengan sungguh-sungguh supaya tujuan dari organisasi dapat tercapai dengan efektif, fungsi ini sangat penting untuk merealisasikan tujuan organaisasi.

Menurut Sudjana dalam (Irwansyah, 2021), pembelajaran merupakan upaya yang dilakukan dengan sengaja oleh pendidik yang dapat menyebabkan peserta didik melakukan kegiatan belajar. Sedangkan Menurut (Hernawan, 2013), pembelajaran pada hakikatnya merupakan suatu proses komunikasi transaksional yang bersifat timbal balik, baik antara guru dengan peserta didik, maupun antara peserta didik dengan peserta didik lainnya, untuk mencapai tujuan yang telah ditetapkan. Komunikasi transaksional adalah bentuk komunikasi yang dapat diterima, dipahami, dan disepakati oleh pihak-pihak yang terkait dalam proses pembelajaran.

Berdasarkan pandangan di atas, Manajemen Perencanaan Dan Pelaksanaan Pendidikan Islam pada proses pembelajaran akan berhasil pada tujuannya dalam meningkatkan mutu pendidikan dengan pengelolaan secara konsisten dan berkelanjutan. Semua harus dilakukan sebagai sebuah kebutuhan dalam membangun mutu pendidikan, tidak hanya dalam memenuhi tuntutan aturan.

Penyelenggaraan pendidikan agama Islam setelah Indonesia merdeka mendapat perhatian serius dari pemerintah. Kedudukan pendidikan Islam dalam sistem pendidikan nasional adakalanya sebagai mata pelajaran dan adakala sebagai lembaga, esensi pendidikan agama Islam terletak pada kemampuan untuk mengemba-ngkan potensi siswa agar menjadi manusia yang beriman dan bertakwa dan dapat tampil sebagai khalifatullah fi al-ardh. Esensi ini menjadi acuan terhadap metode pembelajaran untuk mencapai tujuan yang maksimal. Islam disamping menekankan kepada umatnya untuk belajar juga menyuruh umatnya untuk mengajarkan ilmunya kepada orang lain, jadi Islam mewajibkan umatnya belajar dan mengajar, sebagaimana yang dijelaskan dalam Al-Qur'an surat At Taubah ayat 122 yang artinya sebagai berikut:

"...Tidak sepatutnya bagi orang-orang yang mu'min pergi semuanya (ke medan perang). Mengapa tidak pergi dari tiap-tiap golongan di antara mereka beberapa orang untuk memperdalam pengetahuan mereka tentang agama dan untuk memberi peringatan kepada kaumnya, apabila mereka telah kembali kepadanya, supaya mereka dapat menjaga dirinya."... (QS. At Taubah: 122).10

Realitas Pendidikan Islam saat ini bisa dibilang telah mengalami masa intellectual deadlock. Diantara indikasinya adalah sebagai berikut : 1) Minimnya upaya pembaharuan, dan kalau ada kalah cepat dengan perubahan sosial, politik dan kemajuan iptek, 2) Tidak banyak melakukan pemikiran kreatif, inovatif dan kritis terhadap isu-isu actual, 3) Model pembelajaran terlalu menekankan pada pendekatan intelektualisme-verbalistik dan pentingnya interaksi edukatif dan komunikasi humanistik antara guru-murid, 4) Orientasi belum optimal terkait pencapaian karakter manusia muslim sebagai khalifah fi al-ardl, pendidikan Islam mengemban tugas penting, yakni bagaimana mengembangkan kualitas sumber daya manusia (SDM) agar umat Islam dapat berperan aktif dan tetap survive di era globalisasi, dalam konteks ini Indonesia sering mendapat kritik, karena dianggap masih tertinggal dalam melakukan pengembangan kualitas manusianya, padahal dari segi kuantitas Indonesia memiliki sumber daya manusia melimpah yang mayoritas beragama Islam. 
Maka penulis tertarik untuk mengadakan penelitian dengan mengangkat sebuah judul Manajemen Perencanaan dan Pelaksanaan Pendidikan Islam di Madrasah Aliyah Al-Hidayah Ibun, mengingat penting penelitian ini untuk menganalisis masalah-masalah pendidikan sehingga diharapkan melahirkan keputusankeputusan yang tepat, dan untuk melakukan perubahan sistem pendidikan sebagai peningkatan mutu pendidikan. Sehingga tujuan penelitian ini adalah untuk memperoleh gambaran dan menganalisis terkait Manajemen Perencanaan Dan Pelaksanaan Pendidikan Islam. Dimana penelitian ini berupaya menggambarkan proses Manajemen Perencanaan Dan Pelaksanaan Pendidikan Islam untuk meningkatkan mutu pendidikan, sehingga penelitian ini diharapkan dapat memberikan jawaban terkait pengelolaan lembaga pendidikan berdasarkan Manajemen Perencanaan Dan Pelaksanaan untuk menghadapi standarisasi yang sangat diperlukan oleh sebuah lembaga pendidikan untuk terus bertahan melayani Pendidikan, permasalahan ini perlu dilakukan penelitian lebih lanjut supaya dapat diketemukan data yang valid dan sekaligus dapat ditentukan alternatif pemecahannya, atas dasar tersebut maka penulis tertarik melakukan penelitian dengan judul "Manajemen Perencanaan Dan Pelaksanaan Pendidikan Islam (Studi Kasus di Madrasah Aliyah Al-Hidayah Ibun).

\section{METODE PENELITIAN}

Metode penelitian yang digunakan pada pendekatan kualitatif ini yaitu dengan metode studi kasus. Metode penelitian yang bertujuan untuk mendeskripsikan suatu situasi atau bidang tertentu secara analisis, sistematis faktual dan teliti. Menurut (Bahri, 2021) mengemukakan bahwa studi kasus adalah "merupakan penelitian yang mencakup pengkajian bertujuan memberikan gambaran secara mendetail mengenai latar belakang, sifat maupun karakter yang ada dari suatu kasus, dengan kata lain bahwa studi kasus memusatkan perhatian pada suatu kasus secara intensif dan rinci". Penelitian dalam metode ini dilakukan secara mendalam terhadap suatu keadaan atau kondisi dengan cara sistematis mulai dari melakukan pengamatan, pengumpulan data, analisis informasi dan pelaporan hasil. Dalam hal ini peneliti lebih banyak berinteraksi dengan subjek penelitian serta mengamati berbagai kegiatan yang ada. Peneliti mengamati berbagai kejadian dan gejala pada kegiatan yang berkaitan dengan Manajemen Perencanaan Dan Pelaksanaan Pendidikan Islam dalam rangka mengungkap data-data Manajemen Perencanaan Dan Pelaksanaan Pendidikan Islam. Suatu kasus menarik untuk diteliti karena corak khas kasus tersebut yang memiliki arti pada orang lain, minimal bagi peneliti.

Penelitian Simple Research Design (SRD) ini menggunkan pendekatan kualitatif. Penggunaan pendekatan ini disesuaikan dengan tujuan pokok penelitian yaitu dalam rangka mengungkap data Manajemen Perencanaan dan Pelaksanaan Pendidikan Islam. Menurut (Sugiyono, 2012) bahwa penelitian kualitatif adalah penelitian yang digunakan untuk meneliti pada kondisis objek yang alamiah, di mana peneliti adalah sebagai instrumen kunci". Sedangkan menurut Moleong dalam (Rahayu, 2020) bahwa penelitian kualitatif adalah "tradisi tertentu dalam ilmu pengetahuan sosial yang secara fundamental bergantung dari pengamatan pada manusia baik dalam kawasannya maupun dalam peristilahannya". Penelitian ini dilaksanakan untuk mendeskripsikan dan menganalisis kegiatan Manajemen Perencanaan Dan Pelaksanaan Pendidikan Islam. Dengan kata lain bahwa kajian penelitian ini pada hakekatnya mengamati kegiatan manusia dalam lingkungan atau organisasi sehubungan dengan pengelolaan Manajemen Perencanaan Dan Pelaksanaan Pendidikan Islam., adapun teknik pengumpulan data yang digunakan dalam penelitian ini diantaranya:

a) Observasi

Pengamatan (observasi) merupakan kegiatan mempelajari suatu gejala dan peristiwa melalui melihat dan mencatat data atau informasi secara sistematis. Menurut (Sugiyono, 2012) bahwa observasi adalah pengamatan secara langsung terhadap suatu kondisi lapangan untuk memperoleh data yang diperlukan. Data observasi terkait hasil penelitian dosen-dosen, dosen dan mahasiswa, dan dosen dengan mitra.

b) Wawancara

Wawancara adalah proses pengumpulan data atau informasi melalui tatap muka antar pihak penanya dengan pihak yang ditanya atau penjawab. Wawancara dilakukan dengan berdasarkan pada pedoman wawancara (interview guide). Dalam kegiatan wawancara peneliti melihat empat komponen yaitu isi pertanyaan, pewawancara, responden, dan situasi wawancara. Responden yang diwawancarai adalah Yayasan, Kepala Sekolah dan Guru. Maksud mengadakan wawancara seperti ditegaskan oleh Lincoln dan Guba 
dalam (Sofyan, 2020) antara lain sebagai berikut: mengkontruksi mengenai orang, kejadian, organisasi, perasaan, motivasi tuntutan kepedulian dan lain-lain kebulatan; merekomendasikan kebulatan-kebulatan demikian sebagai yang dialami masa lalu; memproyeksikan kebulatan-kebulatan sebagai yang diharapkan untuk dialami pada masa yang akan datang; memverifikasi, mengubah, dan memperluas informasi yang diperoleh dari orang lain, baik manusia maupun bukan manusia (triangulasi); dan memverifikasi, mengubah, dan memperluas kontruksi yang dikembangkan oleh peneliti sebagai pengecekan anggota.

c) Dokumentasi

Adapun perolehan data dalam penelitian ini dilakukan dengan mempelajari berbagai sumber dokumentasi yang berada di Sekolah yang diteliti. Studi dokumentasi dilakukan dengan cara mengumpulkan, menganalisis dokumen-dokumen, catatan-catatan yang penting dan berhubungan serta dapat memberikan data-data untuk memecahkan permasalahan dalam penelitian. Menurut (Sugiyono, 2012) mendefinisikan mengenai studi dokumentasi bahwa Dokumen merupakan catatan peristiwa yang sudah berlalu. Dokumen bisa berbentuk tulisan, gambar, atau karya- karya monumental dari seseorang. Dokumen yang berbentuk tulisan, misalnya catatan harian, sejarah kehidupan (life histories), cerita, biografi, peraturan kebijakan. Pemanfaatan dokumentasi sebagai salah satu sumber data merupakan hal yang sangat penting karena dapat membantu penulis merumuskan hasil penelitian.

Sedangkan Sumber data dalam penelitian ini adalah subyek dari mana data dapat diperoleh. Suharsimi Arikunto (Arikuntoro, 2006) mengemukakan bahwa sumber data adalah "subjek dari mana data dapat diperoleh". Pada penelitian ini tekhnik pengumpulan datanya menggunakan wawancara, dengan sumber data disebut responden yakni orang yang merespon atau menjawab pertanyaan-pertanyaan peneliti, baik pertanyaan tertulis maupun lisan dalam rangka mengungkap data-data Manajemen Perencanaan Dan Pelaksanaan Pendidikan Islam. Adapun datadata dalam penelitian ini yakni sebagai berikut : 1) Data Primer adalah sumber data yang langsung memberikan data kepada pengumpul data, dan 2) Data Sekunder adalah sumber data yang diperoleh dengan cara membaca, mempelajari dan memahami melalui media lain yang bersumber dari literatur, buku-buku, serta dokumen.

\section{HASIL DAN PEMBAHASAN}

\section{A. Deskripsi data Penelitian}

Agar dalam memperoleh hasil yang lebih obyektif dalam penelitian ini, maka peneliti melakukan wawancara langsung dengan guru yang bersangkutan, dan observasi pada waktu proses pembelajaran berlangsung di kelas sebagai salah satu bentuk dari penyelenggaraan pendidikan Islam agar hasil penelitian ini nantinya bisa dipertanggungjawabkan kebenarannnya tanpa adanya manipulasi data yang akan dipaparkan. Hasil wawancara dan observasi tentang perencanaan dan pelaksanaan pendidikan Islam di Madrasah Aliyah Al-Hidayah Ibun, akan dijelaskan hasil datanya sebagai berikut:

1. Perencanaan pendidikan Islam pada proses Pembelajaran di MA Al-Hidayah Ibun

Guru membuat perangkat pembelajaran seperti RPP, Prota dan Promes, menetapkan tujuan pembelajaran, memilih dan mengembangkan bahan pengajaran, memilih media pengajaran yang sesuai, memilih dan memanfaatkan sumber belajar, hal ini dapat diketahui dari hasil wawancara kepada guru mata pelajaran Al-Qur'an Hadits dan sejarah kebudayaan Islam, bahwa guru yang bersangkutan membuat perangkat pembelajaran seperti RPP, Prota, Promes, menetapkan tujuan pembelajaran, tujuan pembelajaran mengacu pada silabus, memilih dan mengembangkan bahan pengajaran, bahan ajar disesuaikan dengan silabus, menggunakan media pengajaran yang sesuai seperti papan tulis, memilih dan memanfaatkan sumber belajar, sumber belajarnya buku dan Al-Qur'an.

Selanjutnya peneliti melakukan observasi untuk menguatkan hasil temuan penelitian, diketahui oleh peneliti bahwa guru mata pelajaran Bahasa Arab bahwa perencanaan pembelajarannya yaitu dengan cara membaca buku Bahasa Arab. Guru membuat perangkat pembelajaran, menetapkan tujuan pembelajaran, memilih dan memanfaatkan sumber belajar. Hal ini dapat diketahui dari hasil wawancara kepada guru mata pelajaran Bahasa yang mengemukakan bahwa membuat perangkat pembelajaran ada di sekolah, saya punya sudah sertifikasi, ya menetapkan 
tujuan pembelajaran sesuai dengan yang termaktub di RPP sama dengan itu (RPP), media kalau di ganjar (RU MA putri) tidak ada, (memilih dan memanfaatkan sumber belajar) sumber belajarnya pertama kalau Bahasa Arab sudah ada di sekolah berupa kitab dan LKS".

2. Pelaksanaan pendidikan Islam pada proses Pembelajaran di MA Al-Hidayah Ibun

Guru menciptakan iklim/suasana pembelajaran yang tepat, mengamati kegiatan pembelajaran, mengatur siswa dalam kegiatan pembelajaran, memilih dan menetapkan metode pembelajaran yang dianggap paling tepatdan efektif, menilai prestasi belajar peserta didik dan melaksanakan tindak lanjut hasil penilaian, hal ini dilakukan jika nilainya kurang dari KKM deangan cara mengadakan remidi. Hal ini dapat diketahui dari hasil wawancara kepada guru mata pelajaran Bahasa Arab yang mengemukakan bahwa pasti menciptakan iklim/suasana pembelajaranyang tepat, agar anak-anak merasa nyaman ketika pembelajaran berlangsung, selalu mengamati kegiatan pembelajaran, saya amati agar anak-anak lebih semangat ketika pembelajaran, sangat bisa mengatur siswa dalam kegiatan pembelajaran, karena siswi-siswi kami perempuan jadi sangat mudah diatur, memilih dan menetapkan metode pembelajaran yang dianggap paling tepat dan efektif, yaitu metode tanya jawab dan musyawarah untuk menterjemah, menurut guru yang bersangkutan bahwa menilai prestasi belajar peserta didik, dan melaksanakan tindak lanjut hasil penilaian, hal ini dilakukan jika nilainya kurang dari KKM deangan cara mengadakan remidi.

Selanjutnya peneliti melakukan observasi untuk menguatkan hasil temuan penelitian, diketahui oleh peneliti bahwa guru mata pelajaran Bahasa Arab yang mengemukakan, menciptakan iklim/ suasana pembelajaran yang tepat, menga-mati kegiatan pembelajaran, dan mengatur siswa dalam kegiatan pembelajaran. Guru mengamati kegiatan pembelajaran, mengatur siswa dalam kegiatan pembelajaran, menilai prestasi belajar peserta didik, dan melaksanakan tindak lanjut hasil penilaian. Hal ini dapat diketahui dari hasil wawancara kepada guru mata pelajaran Al-Qur'an Hadits dan sejarah kebudayaan Islam yang mengatakan: jelas (dapat mengamati kegiatan pembelajaran) diamati, mampu (mengatur siswa dalam kegiatan pembelajaran) karena kalau anak perempuan lebih mudah, yang perlu diatur motivasi belajarnya (menilai prestasi belajar peserta didik) prestasi belajarnya kalau kelas dua dan tiga sudah bagus, kalau kelas satu masih mengevaluasi tentang definisi-definisi AlQur'an, ya (melaksanakan tindak lanjut hasil penilaian) tindak lanjutnya baca $\mathrm{Al}-$ Qur'an yang penting.

Peneliti melakukan observasi untuk menguatkan hasil temuan penelitian, diketahui oleh peneliti bahwa guru mata pelajaran Al-Qur'an Hadits dan sejarah kebudayaan Islam, mengamati kegiatan pembelajaran, dan mengatur siswa dalam kegiatan pembelajaran. Guru mengamati kegiatan pembelajaran, mengatur siswa dalam kegiatan pembelajaran, memilih dan menetapkan metode pembelajaran yang dianggap paling tepatdan efektif, menilai prestasi belajar peserta didik, dan melaksanakan tindak lanjut hasil penilaian. Hal ini dapat diketahui dari hasil wawancara kepada guru mata pelajaran Bahasa Arab yang mengatakan: setelah diamati sebab kalau tidak dimati kadang-kadang anak itu dalam satu kelas itu yang konsenterasi cuma satu dua tiga, kalau dibiarkan anak berantakan, harus diamati jangan sampai terlepas dari pengamatan guru, ya mampu mengatur, murid yang sudah ada di depan sudah mengatur dengan sendirinya, yang perlu diatur yang paling belakang sendiri, (memilih dan menetapkan metode pembelajaran yang dianggap paling tepatdan efektif), pertama yang biasa ceramah kemudian tanya jawab, kemudian sebulum itu baca fatihah, evaluasi diadakan biyasanya satu bulan sekali, ya (tindak lanjut hasil penilaian), yang sangat parah diremidi.

\section{B. Analisis Hasil Penelitian}

1. Perencanaan pendidikan Islam pada proses Pembelajaran di MA Al-Hidayah Ibun Para ahli pendidikan pada umumnya, mengemukakan empat langkah besar sebagai prosedur penyusunan rencana 
pengelolaan PBM, yaitu sebagai berikut: Pertama, merumuskan dan menetapkan spesifikasi output (kekhususan dan tingkat keahlian para lulusan) yang menjadi target yang hendak dicapai dengan memperhatikan aspirasi dan selera serta kebutuhan masyarakat yang memerlukan output tersebut. Kedua, mempertimbangkan dan memilih cara atau pendekatan dasar proses belajar mengajar yang dipandang paling efektif untuk mencapai target. Ketiga, mempertimbangkan dan menetapkan langkahlangkah tepat yang akan ditempuh sejak titik awal hingga titik akhir yaitu tercapainya hasil PBM. Keempat, mempertimbangkan dan menetapkan kriteria (ukuran yang menjadi dasar) dan standar (tolak ukur/ patokan) yang akan dipergunakan untuk mengevaluasi taraf keberhasilan PBM.

2. Pelaksanaan Pendidikan Islam Pada proses pembelajaran Madrasah Aliyah Al-Hidayah Ibun

Dalam melaksanakan rencana kegiatan PBM, guru seyogianya pandai-pandai menen-tukan pendekatan sistem pengajaran yang benar-benar pas dengan sifat pokok bahasan, kemampuan siswa, dan tujuan instruksional yang hendak dicapai. Di antara sistem-sistem instruksional yang masyhur dan telah dimodifikasi atau revisi oleh para ahli adalah:

a) Sistem enquiry-discovery, yang kurang lebih berarti belajar penyelidikan dan penemuan, proses belajar mengajar dengan sistem ini, menghendaki guru untuk menyajikan bahan pelajaran tidak dalam bentuk yang final (utuh dari awal hingga akhir) atau dengan kata lain guru hanya menyajikan sebagian.

b) Sistem expository merupakan kebalikan dari sistemenquiry-discovery, sistem expo-sitory digunakan guru untuk menyaj-ikan bahan pelajaran secara utuh atau menyeluruh, lengkap dan sistematis, dengan penyampaian secara verbal.

c) Sistem learning for masrery pada dasarnya merupakan pendekatan yang mengacu pada penetapan kriteria hasil belajar, pengajaran dengan model ini dapat dilaksanakan, baik secara individual maupun secara kelompok.

d) Sistem humanistic aducation (pendidikan yang bersifat kemanusiaan) adalah sebuah sistem klasik yang bersifat global. Pendekatan system pendidikan ini menekankan pengembangan martabat manusia yang bebas membuat pilihan dan berkeyakinan.

Ada empat strategi dasar menurut (Djamarah, 2006) dalam belajar mengajar yang meliputi hal-hal sebagai berikut:

a) Spesifikasi dan kualifikasi perubahan tingkah laku yang bagaimana diinginkan sebagai hasil belajar mengajar yang dilakukan itu, disini terlihat apa yang dijadikan sebagai sasaran dari kegiatan belajar mengajar. Sasaran yang dituju harus jelas dan terarah.

b) Memilih cara pendekatan belajar mengajar yang dianggap paling tepat dan efektif untuk mencapai sasaran, bagaimana seorang guru memandang suatu persoalan, konsep, pengertian dan teori apa yang guru gunakan dalam memecahkan suatu kasus, akan mempengaruhi hasilnya.

c) Memilih dan menetapkan prosedur, metode, dan teknik belajar mengajar yang dianggap paling tepat dan efektif, metode atau teknik penyajian untuk memotivasi anak didik agar mampu menerapkan pengetahuan dan pengalamannya untuk memecahkan masalah, berbeda dengan cara atau metode supaya anak didik terdorong dan mampu berpikir dan bebas dan cukup keberanian untuk mengemukakan pendapatnya sendiri.

d) Menerapkan norma-norma atau kriteria keberhasilan sehingga guru mempunyai pegangan yang dapat dijadikan ukuran untuk menilai sampai sejauh mana keberhasilan tugas-tugas yang telah dilakukanya, suatu program baru bisa diketahui keberhasilannya, setelah melakukan evaluasi.

\section{SIMPULAN DAN SARAN}

\section{A. Simpulan}

Dari hasil penelitian yang peneliti lakukan untuk mengetahui perencanaan dan pelaksanaan pendidikan islam pada proses pembelajaran di Madrasah Aliyah AlHidayah Ibun. Baik dengan menggunakan 
metode observasi maupun wawancara, maka dapat disimpulkan hasil datanya antara lain: a) Perencanaan pendidikan islam pada proses pembelajaran di MA Al-Hidayah Ibun, yaitu: 1) Guru membuat perangkat pembelajaran, 2) Guru menetapkan tujuan pembelajaran, 3) Guru memilih dan mengembangkan bahan pengajaran, 4) Guru memilih media pengajaran yang sesuai, dan 5) Guru memilih dan memanfaatkan sumber belajar, b) Pelaksanaan pendidikan islam pada proses pembelajaran di MA Al-Hidayah Ibun diantaranya: 1) Guru menciptakan iklim/ suasana pembelajaran yang tepat, 2) Guru mengamati kegiatan pembelajaran, 3) Guru mengatur siswa dalam kegiatan pembelajaran, 4) Guru memilih dan menetapkan metode pembelajaran yang dianggap paling tepat dan efektif, 5) Guru menilai prestasi belajar peserta didik, dan 6) Guru melaksanakan tindak lanjut hasil penilaian.

\section{B. Saran}

Adapun saran yang dapat disampaikan berdasarkan pada hasil penelitian ini, yaitu: a) Peningkatan saran dan prasarana pembelajaran pada madrasah dalam meningkatkan mutu pendidikan islam, b) Meningkatkan motivasi siswa madrasah dalam proses pembelajaran, c) Mengoptimalkan pengawasan dalam meningkatkan mutu pendidikan islam.

\section{DAFTAR RUJUKAN}

Arifudin, 0. (2018). Pengaruh Pelatihan Dan Motivasi Terhadap Produktivitas Kerja Tenaga Kependidikan STIT Rakeyan Santang Karawang. MEA (Manajemen, Ekonomi, \& Akuntansi), 2(3), 209-218.

Arifudin, O. (2021). Konsep Dasar Pendidikan Anak Usia Dini. Bandung: Widina Bhakti Persada Bandung.

Arikuntoro, S. (2006). prosedur penelitian suatu pendekata praktik. Jakarta:Rineka Cipta.

Bahri, A. S. (2021). Pengantar Penelitian Pendidikan (Sebuah Tinjauan Teori dan Praktis). Bandung: Widina Bhakti Persada.

Bairizki, A. (2021). Manajemen Perubahan. Bandung : Widina Bhakti Persada.
Djamarah. (2006). Strategi Belajar Mengajar. Jakarta: PT Rineka Cipta.

Hasbi, I. (2021). Administrasi Pendidikan (Tinjauan Teori Dan Praktik). Bandung: Widina Bhakti Persada.

Hasibuan. (2016). Manajemen Sumber Daya Manusia. Edisi Revisi. Jakarta: Penerbit PT Bumi Aksara.

Irwansyah, R. (2021). Perkembangan Peserta Didik. Bandung : Widina Bhakti Persada.

Juhji. (2020). Manajemen Humas Sekolah. Bandung: Widina Bhakti Persada.

Mayasari, A. (2021). Implementasi Sistem Informasi Manajemen Akademik Berbasis Teknologi Informasi dalam Meningkatkan Mutu Pelayanan Pembelajaran di SMK. JIIPJurnal Ilmiah Ilmu Pendidikan, 4(5), 340345.

https://doi.org/https://doi.org/10.54371/i iip.v4i5.277

Muhibin. (2008). Psikologi Pendidikan dengan Pendekatan Baru. Bandung: PT Remaja Rosdakarya.

Nadeak, B. (2020). Manajemen Humas Pada Lembaga Pendidikan. Bandung: Widina Bhakti Persada.

Rahayu, Y. N. (2020). Program Linier (Teori Dan Aplikasi). Bandung : Widina Bhakti Persada.

Sofyan, Y. (2020). Peranan Konseling Dosen Wali Dalam Meningkatkan Motivasi Belajar Mahasiswa Di Perguruan Tinggi Swasta Wilayah LLDIKTI IV. Jurnal Bimbingan Dan Konseling Islam, 10(2), 237-242.

Sugiyono. (2012). Metode penelitian pendidikan. Bandung: Alfabeta.

Tafsir. (2012). Ilmu Pendidikan Islam. Bandung: Remaja Rosdakarya. 